\title{
Engineering and Economic Analysis of the Synthesis of Fluoride Tin Oxide Film Production
}

\author{
Asep Bayu Dani Nandiyanto, Tsabbit Aidil Aziz, Ruslan Fariansyah \\ Departemen Kimia, Universitas Pendidikan, Jl. Dr. Setiabudi no 229, Bandung 40154, Jawa Barat, INDONESIA \\ nandiyanto@upi.edu
}

\begin{abstract}
The purpose of this study was to analyze the Fluoride Tin Oxide $\left(\mathrm{SnO}_{2} / \mathrm{F}\right)$ production in home-scale industry in engineering point of view and economic evaluation perspective. This material is considered due to its wide range of energy-related applications. Evaluation of the $\mathrm{SnO}_{2} / \mathrm{F}$ production in engineering perspective is conducted from the selection of the most economical process, mass balance calculation, to the adaptation in the commercially available apparatuses. Evaluation of the production from the economic point of view is done by calculating economic parameters: Gross Profit Margin, Internal Rate Return, Payback Period, Cummulative Net Present Value, Profitability Index, and Breakeven Point. In short of the production process, we used the pure tin (as the metal precursor) and ammonium fluoride (as the source of Flouride for doping). The engineering point of view showed that the process is able to produce conductive glass that can be used as the active electrode substrate in the solar cell. Economic evaluation showed that the process is profitable, confirmed by the positive values from all economic parameters. However, for some cases that are compared to the market and the local bank interest, the process is not attractive for investor. Thus, to make them attractive, support from government or corporate social responsibility is required.
\end{abstract}

Keywords: energy, tin oxide production, conductive glass

Received: 01/12/2017 - Accepted: 20/12/2017

\section{Introduction}

Recently, energy has become a major problem in many aspects. One of the objects related to energy is how to manage the source of energies and materials for energy conversion or transfer. In the field of solar energy, solar rays are used to produce drinking water [1], or to produce electrical energy [2] and thin layers of different materials are used to produce conductive glass plates and semiconductor [3-4]

Tin oxide is one of the attractive energy-related materials because this material has a wide band gap with a low $n$-type resistivity (1023 V.cm) and high transparency $(90 \%)$ in the visible region. Interestingly, resistivity of this material can be reduced further to the range of $1024 \mathrm{~V} . \mathrm{cm}$ by additional doping, which is suitable for application in thin film solar cells. Tin oxide has also been known in the fabrication of gas sensors due to sensitivity of its surface conductance to gas adsorption $[5,6]$. This makes tin oxied has been well-documented from preparation techniques to the control of properties $[7,8]$. For example, fabrication techniques for preparing tin oxide has been well reported, including dip coating, evaporation, sputtering, chemical vapor deposition, and spray pyrolysis [9].

Many raw materials for tin oxide has been also reported, such as tin chloride (e.g. $\mathrm{SnCl}_{2}[10]$ and $\mathrm{SnCl}_{4}$ [11] ) and tin fluoride. The tin material was also combined with several doping component [12], such as antimony ( $\mathrm{Sb})$, chloride

(Cl) [13,14], bromide (Br) [11-15], and fluoride (F) [11]. Some reports showed that fluoride is the most effective dopants [11, 16-19].

Although synthesis of tin oxide is well documented, the papers are discussed for the laboratory scale production only. No information about economic evaluation is found, while this information is important. This is because economic evaluation relates to the further studies for scaling up production. Based on our previous studies on the mathematical analysis[20, 21], the purpose of this study was to analyze the engineering point of view and economic evaluation of the flourinet in oxide $\left(\mathrm{SnO}_{2} / \mathrm{F}\right)$ production for home-scale industry. 


\section{Method}

In this study, we analyzed the feasibility study on the fabrication of $\mathrm{SnO}_{2} / \mathrm{F}$ in home-scale industry. The feasibility study was done in two ways: engineering evaluation and economic analysis. Evaluation of the $\mathrm{SnO}_{2} / \mathrm{F}$ production in engineering perspective is conducted from the selection of the most economical process, mass balance calculation, to the adaptation in the commercially available apparatuses. Evaluation of the production from the economic point of view is done by calculating economic parameters: Gross Profit Margin (GPM), Internal Rate Return (IRR), Payback Period (PBP), Cumulative Net Present Value (CNPV), Profitability Index (PI), and Breakeven Point (BEP).

\section{Results and discussion}

\section{III.1 engineering evaluation}

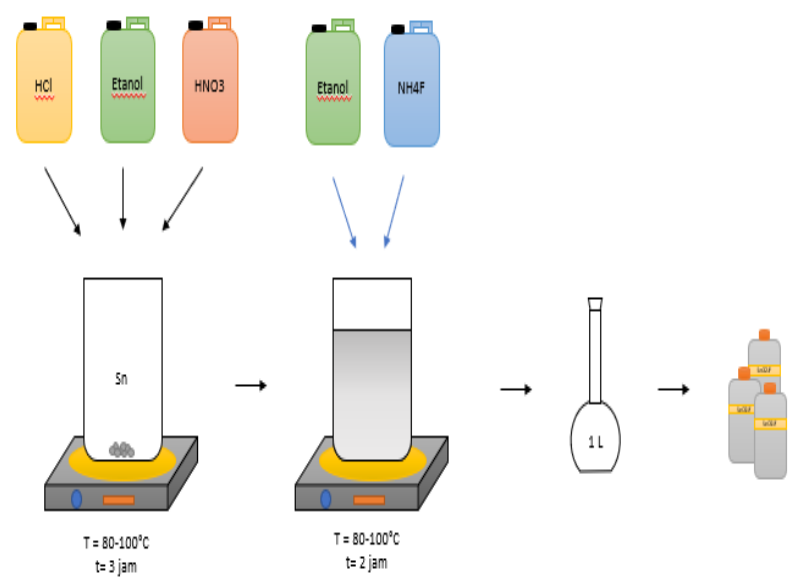

Figure 1. Chart of $\mathrm{SnO}_{2} \cdot \mathrm{F}$ production

Figure 1 shows the process diagram for thehomescale production of $\mathrm{SnO}_{2} / \mathrm{F}$. The manufacturing process described with some steps. First step,tin metal was mixed and dissolved in hydrochloric acid and nitric acid at temperature of $80-100^{\circ} \mathrm{C}$.[22] The process was maintained until all acid component evaporates (forming $\mathrm{SnCl} 2$ yellow precipitated).[23,24] Then,the evaporated component was added by ethanol and ammonium fluoride solution for oxidation process for about 2 hours. The process was maintained in the same temperature condition.[25]The final product yields a solution of $\mathrm{SnO}_{2} . \mathrm{F}$ in ethanol and then packed in 1-liter bottle for sale to markets.During the process, the following chemical reactions happen:

For dissolution process:

$\mathrm{Sn} \rightarrow \mathrm{Sn}^{2+}$

For formation chloride tin:

$\mathrm{Sn}^{2+}+2 \mathrm{Cl}^{-} \rightarrow \mathrm{SnCl}_{2}$

For oxidation process:
$\mathrm{SnCl}_{2}+2 \mathrm{C}_{2} \mathrm{H}_{5} \mathrm{OH}+\mathrm{NH}_{4} \mathrm{~F}+8 \mathrm{O}_{2} \rightarrow \mathrm{SnO}_{2} / \mathrm{F}+4 \mathrm{CO}_{2}+1 / 2$ $\mathrm{N}_{2}+8 \mathrm{H}_{2} \mathrm{O}+\mathrm{Cl}_{2}$

Based on the diagram process in Figure 1, several assumptions are added:

1. The conversion rate in all reactions is $100 \%$.

2. During the process, ethanol is oxidized and losses about $20 \%$.

3. Then, using analysis of commercially available apparatus in market for home-scaling industry, the product can be generated in one batch process is 933 $\mathrm{mL}$ of concentrated $\mathrm{SnO}_{2} / \mathrm{F}$.

\section{III.2 Economic evaluation}

To ensure the economic evaluation, the analysis of GPM firstly evaluated. The GPM value for the 1 year $\mathrm{SnO}_{2} / \mathrm{F}$ home-scale production can reach more than 220 million rupiahs. Or, using exchange rate for 1 USD = $10,000 \mathrm{Rp}$, we can get the GPM value can reach more than USD 22,000. Calculation with the initial raw material, the profit can reach about $200 \%$. The percentage of profit was calculated from the comparison between the results of products sales with purchased raw materials needed for the production.Based on the results of GPM calculation, the production of $\mathrm{SnO}_{2} / \mathrm{F}$ is quite profitable.

Further analysis of the process is shown in Figure 2.This figure shows the CNPV analysis of $\mathrm{SnO}_{2} / \mathrm{F}$ production. The curve shows the relationship between the value of CNPV and total investment cost (TIC) in the operating years (20 years of production). The result showed that the initial time can result negative CNPV. But, after PBP years (about 4 years), the project is profitable.

The calculations for PI, IRR, BEP and last CNPV / TIC are $10 \%, 68 \%, 1,3.51 \%$, respectively. Based on the data, the PI may explain that this production project is not feasible to proceed from a PI value of only $10 \%$ or 0.1 , where the minimum eligibility value of a project is greater than 1 [23]. IRR value describes the amount of return that will be obtained from the total value of investment that has been issued as the main capital. Thus, with an IRR of $68 \%$, the amount of returns that will be obtained in the future is quite large. Based on calculations in the production of $\mathrm{SnO}_{2} . \mathrm{F}$, the value of BEP obtained is 1 unit. This value mean the minimum quantity of products that can be produced is just 1 unit product per day. Further, last CNPV / TIC explained that in 20 years of production value of the rate of profit from the TIC issued is $3.51 \%$. Compared to local bank interest at20 October 20, the value is relatively lower. Local bank interest shows a value of $4.35 \%$ [24].Thus, this project is relatively not interesting for investor. 


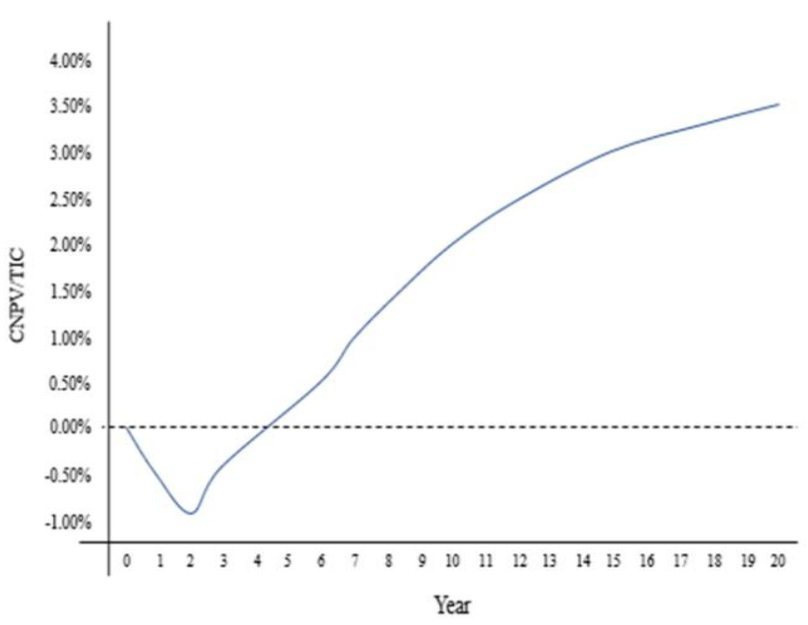

Figure 2. Correlation between CNPV graph in one year of production

\section{Conclusion}

The production of $\mathrm{SnO}_{2} / \mathrm{F}$ in the home-scale industry has been evaluated from engineering and economic perspective. Based on the project, the engineerig point of view shows the possibility for the production of $\mathrm{SnO}_{2} / \mathrm{F}$ in home scale. Economic evaluation showed that the project is profitable, confirmed by the positive values from all economic parameters. However, compared to the market and the local bank interest, the process is not attractive for investor. Thus, to make them attractive, support from government or corporate social responsibility is required.

\section{References}

[1] A. Khechekhouche, A. Boukhari, Z. Driss, N. Benhissen. Seasonal effect on solar distillation in the El-Oued region of south-east Algeria. Vol 2; Issue 1, 2017, pp 42-45.

[2] M. Maamir, A. Betka, H. Aboub. Modeling and Simulation of Energy Management Hybrid Sources System composed of SolarPV and Battery. International Journal of Energetica, vol1; issue1, 2016; pp 12-19.

[3] Achour Rahal, Said Benramache, Boubaker Benhaoua, Preparation of n-type semiconductor $\mathrm{SnO} 2$ thin films. Journal of Semiconductors.Vol 2 issue 2. 2013 https://doi.org/10.1088/16744926/34/8/083002

[4] Nandiyanto, A. B. D., Sofiani, D., Permatasari, N., Sucahya, T. N., Wiryani, A. S., Purnamasari, A., Rusli, A.,\& Prima, E. C. Photodecomposition profile of organic material during the partial solar eclipse of 9 march 2016 and its correlation with organic material concentration and photocatalyst amount. Indonesian Journal of Science and Technology, 1(2), 2016, pp 132-155.

[5] Britt, J., \&Ferekides, C. Thin-film CdS/CdTe solar cell with 15.8\% efficiency. Applied Physics Letters, 62(22), 1993, pp 2851-2852.

[6] Das, S. K., \& Morris, G. C. Preparation and properties of electrodeposited indium tin oxide/SnO2/CdTe and indium tin oxide/SnO2/CdS/CdTe solar cells. Journal of applied physics, 73(2), 1993, pp 782-786.

[7] Watson, J., Ihokura, K., \& Coles, G. S. The tin dioxide gas sensor. Measurement Science and Technology, 4(7), 1993, pp 711

[8] Yoo, D. J., Tamaki, J., Park, S. J., Miura, N., \&Yamazoe, N. H2S sensing characteristics of $\mathrm{SnO}_{2}$ thin film prepared from $\mathrm{SnO}_{2}$ sol by spin coating. Journal of materials science letters, 14 (19), 1995 , pp 1391-1393.

[9] Dawar, A. L., \& Joshi, J. C. Semiconducting transparent thin films: their properties and applications. Journal of Materials Science, 19(1), 1984, pp 1-23.

[10] Jordan, J. F., \& Albright, S. P. Large-area CdS/CdTe photovoltaic cells. Solar cells, 23(1-2), 1988, pp 107-113.

[11] Agashe, C., \& Major, S. S. Effect of F, Cl and $\mathrm{Br}$ doping on electrical properties of sprayed $\mathrm{SnO} 2$ films. Journal of materials science letters, 15(6), 1996, pp 497-499.

[12] Morris, G. C., \&McElnea, A. E. Fluorine doped tin oxide films from spray pyrolysis of stannous fluoride solutions. Applied surface science, 92, 1996, pp 167-170.

[13] Shanthi, E., Dutta, V., Banerjee, A., \& Chopra, K. L. (1980). Electrical and optical properties of undoped and antimony-doped tin oxide films. Journal of Applied Physics, 51(12), pp 62436251.

[14] Unaogu, A. L., \&Okeke, C. E Characterization of antimonydoped tin oxide films prepared by spray pyrolysis. Solar energy materials, 20(1-2), 1990, pp 29-36.

[15] Abass, A. K. Electrical and optical properties of chlorine doped SnO2 coatings. Solid state communications, 61(8), 1987, pp 507510 .

[16] Mohammad, M. T., \& Abdul-Ghafor, W. A. Properties of fluorine-doped $\mathrm{SnO} 2$ films prepared by the spray pyrolysis technique. physica status solidi (a), 106(2), 1988, pp 479-484.

[17] Cowache, P., Lincot, D., \&Vedel, J. Cathodic codeposition of cadmium telluride on conducting glass. Journal of The Electrochemical Society, 136(6), 1989, pp 1646-1650.

[18] Afify, H. H., Momtaz, R. S., Badawy, W. A., \& Nasser, S. A. Some physical properties of fluorine-doped $\mathrm{SnO} 2$ films prepared by spray pyrolysis. Journal of Materials Science: Materials in Electronics, 2(1), 1991, pp 40-45.

[19] Grosse, P., Schmitte, F. J., Frank, G., \&Köstlin, H. Preparation and growth of $\mathrm{SnO}_{2}$ thin films and their optical and electrical properties. Thin Solid Films, 90(3), 1982, pp 309-315.

[20] Andika, R., \& Valentina, V. Techno-economic Assessment of Coal to SNG Power Plant in Kalimantan. Indonesian Journal of Science and Technology, 1(2), 2016, pp156-169.

[21] Nandiyanto, A. B. D. Mathematical Approximation Based on Thermal Analysis Curves for Calculating Kinetic Parameters of Thermal Decomposition of Material.Journal of Engineering Science and Technology, 12, 2017, pp 76-90

[22] Surahman, H., Krisnandi, Y. K., \&Gunlazuardi, J. Preparation and characterization of transparent conductive $\mathrm{SnO} 2-\mathrm{F}$ thin film deposited by spray pyrolysis: relationship between loading level and some physical properties. Procedia Environmental Sciences, 28, 2015, pp 242-251.

[23] Vera, D., Carabias, J., Jurado, F., \& Ruiz-Reyes, N. A Honey Bee Foraging approach for optimal location of a biomass power plant. Applied Energy, 87(7), 2010, pp 2119-2127.

[24] Agusman. Bank Indonesia Mempertahankan Suku Bunga Kebijakan: Ekonomi Global Membaik, PemulihanEkonomi Domestik Berlanjut. Jakarta :DepartemenKomunikasi. No.19/79/Dkom. 2017

[25] Riveros, R., Romero, E., \& Gordillo, G. Synthesis and characterization of highly transparent and conductive SnO2: F and In2O3: Sn thin films deposited by spray pyrolysis. Brazilian journal of physics, 36(3B), 2006, pp 1042-1045. 